\title{
ANALISIS DIGITAL MARKETING PADA HOTEL KILA DI KABUPATEN LOMBOK BARAT TERHADAP KEPUASAN KONSUMEN
}

\author{
Menik Aryani \\ Fakultas Ilmu Pendidikan dan Psikologi, Universitas Pendidikan Mandalika \\ Email: menikaryani81@gmail.com
}

\begin{abstract}
Abstrak: Penelitian ini berjudul "Analisis Digital Marketing Pada Hotel Kila Di Kabupaten Lombok Barat Terhadap Kepuasan Konsumen”. Penelitian ini dilakukan di Hotel Kila Sengiggi Beach, dengan jumlah responden 100 orang. Konsumen yang dijadikan responden pada penelitian ini diambil secara acak dan telah menginap lebih dari tiga kali. Penelitian ini bertujuan untuk melihat analisis digital marketing yang berpengaruh terhadap kepuasan konsumen. Dalam penelitian ini ada 2 (dua ) variable yang diteliti yaitu aksesbilitas dan interaktivitas. Analisis data yang digunakan adalah AnalisisFishbein Attitudeanalisis ini digunakan untuk mengetahui digital marketing yang mana yang paling responden tertarik sehingga memiliki keinginan untuk menginap kembali di Hotel Kila Sengiggi Beach. Berdasarkan analisis kepuasan konsumen menunjukkan konsumen sudah merasa puas dengan layanan digital marketing yang diberikan Hotel Kila Sengiggi Beach. Hal ini dapat dibuktikan dengan hasil rata-rata sikap responden terhadap variabel digital marketing Hotel Kila Sengiggi Beach di atas angka 3,00. Dan dari ke-dua variabel digital marketing layanan variable aksesbilitasmemiliki angka tertinggi yaitu 3,46, sehingga hal itu yang membuat konsumen merasa puas dan berperilaku untuk menginap lagi di Hotel Kila Sengiggi Beach.
\end{abstract}

Keywords :Digital Marketing, kepuasan konsumen.

\section{PENDAHULUAN}

Berbicara tentang perkembangan destinasi wisata dan halal di Indonesia, pastilah pikiran kita akan langsung mengarah kepada pulau Lombok. Pulau Lombok menjadi pemenang salah satu peraih penghargaan sebagai World's Best Halal Honeymoon Destination dan World's Best Halal Tourism Destination dalam acara The World Halal Travel Summit/Exhibition di Abu Dhabi pada tahun 2015 yang lalu. Hal ini pulau Lombok meraih penghargaan sebagai tujuan wisata halal bulan madu dan destinasi wisata halal terbaik didunia yang dapat mengalahkan kandidat Negara-negara muslim lainnya. Dalam hal ini pemerintah daerah terus membangun dan menyiapkan sarana dan prasarana kearah sana. Setiap wisatawan muslim yang datang kelombok, tidak akan kesulitan dalam melaksanakan ibadah. Sarana musholla dan masjid harus ada disetiap 
tempat wisata. Termasuk ketersediaan makanan halal di café atau restaurant. Dibuat senyaman mungkin bagi wisatawan dalam melaksanakan ibadah ketika berwisata.

Pulau Lombok menjadi salah satu destinasi wisata karena keindahan alam serta banyaknya objek wisata yang ada di pulau Lombok seperti wisata alam, wisata pantai, wisata budaya dan wisata kuliner. Salah satu objek destinasi wisata yang di sukai oleh wisatawan adalah destinasi pantai, terutama di pantai sengiggi Lombok barat, pantai 3 gili di Lombok Utara. Di Lombok baru ada 10 hotel berbintang, salah satunya adalah pool villa hotel Kila Sengiggi Beach, hotel ini juga sekaligus merupakan hotel yang memiliki sertifikat halal yang di berikan oleh Provinsi NTB. Hotel ini merupakan hotel bintang 4 dengan pool villa yang berbintang 5 , berlokasi tepat di semenanjung pantai Senggigi. Hotel ini di kelilingi oleh hamparan kebun kelapa seluas 2 hektar dan pantainya yang berpasir putih.Hotel ini sangat populer baik di kalangan mancanegara dan domestik karena letaknya yang strategis, fasilitas yang mewah dan access ke pantainya yang sangat menakjubkan.hotel Kila Sengiggi Beach mengalami beberapa kali renovasi mengenai fasilitas yang diberikan. Terakhir adakan perbaikan (renovasi) dan mengalami pengurangan kamar sehingga menjadi sejumlah 150 kamar, karena 2 kamar Superrior dialih fungsikan menjadiFood \& Beverage Office.Renovasi pada saat itu juga merubah istilah kamar yang dulunya bernama Standard, Superior, Deluxe, menjadi:

\section{Garden Room \\ 2. Beach Bungalow \\ 3. Deluxe Bungalow \\ 4. Garuda Presidential Suite}

Seiring berjalannya waktu dan sebagai perusahaan yang berkomitmen untuk terus berkembang dan berinovasi, Aerowisata Hotels \& Resorts yang berada di bawah PT Aerowisata, mencanangkan tahun 2014 sebagai Tahun Transformasi. Menargetkan pertumbuhan yang signifikan di tahun mendatang, Aerowisata Hotels \& Resorts melakukanrebranding serta perubahan pada konsep pelayanan. 
Langkah awal menapaki tahun transformasi ini adalah dengan melakukan rebrandingportofolio Aerowisata Hotels \& Resorts. Hal ini penting guna menciptakan high brand equity.

Untuk menjaga eksistensi dan pengembangan, Aerowisata Hotels \& Resorts memperkenalkan tiga konsep baru, yaitu:

\section{Prama untuk kategori upscale}

Hotel-hotel dalam kategori Prama ditujukan bagi para wisatawan individu maupun keluarga, pimpinan perusahaan yang ingin menghadiri pertemuan bisnis dan MICE. Diperuntukkan bagi tamu yang menginginkan hotel dengan lokasi strategis, dilengkapi berbagai fasilitas mewah ramah lingkungan. Termasuk dalam Prama adalah Prama Sanur Beach Bali, Prama Grand Preanger Bandung dan Prama Sthala Ubud Bali .

\section{Kila untuk kategori midscale}

Segmentasi pasar untuk Kila adalah untuk wisatawan individu maupun berkeluarga dan pelaku bisnis yang akan menghadiri pertemuan bisnis/MICE. Namun, selain mementingkan lokasi hotel dan fasilitas, tamu juga tetap mempertimbangkan harga kompetitif yang ditawarkan oleh hotel. Termasuk dalam kategori Kila adalah Kila Senggigi Beach Lombok, Grand Artos Hotel Magelang serta Kila Infinity 8.

\section{Asana untuk kategori economy}

Hotel Asana sangat serasi untuk tamu-tamu yang menginap satu atau dua hari saja, sehingga tidak memerlukan fasilitas yang mewah dan lengkap. Lokasi hotel, kebersihan dan harga yang terjangkau merupakan unsur utama bagi para tamu dalam memilih akomodasi di kategori ini. Hotel Asana tersebar di berbagai wilayah di Indonesia, yaitu Asana Kawanua Jakarta, Asana Biak Papua, Asana Mandalika Lombok, dan Asana Agung Putra Bali.

Upaya yang bisa Hotel Kila lakukan untuk mempertahankan eksistensinya terutama di kondisi pandemic ini dengan melakukan digital marketing yang gencar dengan melakukan pembinaan hubungan yang baik dengan konsumen yang belum pernah menginap dan yang sudah pernah menginap. Karena salah satu unsur penting dari suatu hubungan antara perusahaan dan konsumen adalah loyalitas konsumen karena kepuasan konsumen. Beberapa pendekatan pemasaran pada era digital marketing tak hanya melakukan pemasaran produk namun 
mendapatkan jangkauan konsumen melalui beberapa hubungan yang diciptakan antara pemasar dengan pelanggannya ketika sebelum melakukan pembelian, melakukan pembelian, serta sesudah melakukan pembelian pada produk. Hubungan antara pemasar serta pelanggan selanjutnya mewujudkan customer relationship marketing yang ditujukan kepada seluruh kegiatan pemasaran yang dimaksudkan kepada pembentukan, pengembangan, serta pemeliharaan keberhasilan hubungan antara perusahaan dan konsumennya. Hotel Kila Sengiggi sudah berusaha maksimal dalam pemasarannya, sehingga para konsumen merasa puas dengan pelayannya baik dari sisi kedekatan dengan calon konsumen maupun dengan konsumen yang sudah pernah menginap itu juga tidak terlapas dari fasilitas yang di berikan oleh Hotel ini .

\section{KAJIAN LITERATUR}

\subsection{Pengertian Digital Marketing}

Menurut para ahli : a. Sánchez-Franco et al., (2014) mendefinisakan pemasaran digital sebagai hasil pemasaran evolusi. Evolusi terjadi ketika perusahaan menggunakan saluran media digital untuk sebagian besar pemasaran. Saluran media digital dapat di atasi dan diizinkan percakapan terus menerus, dua arah, dan pribadi antara pemasar dan konsumen. b. Kaufman dan Horton (2014) menunjukkan pemasaran digital sebagai model pemasaran non tradisional. c. Menurut Lane (2008) dalam (Katherine Taken Smith, 2011) pemasaran digital adalah praktik mempromosikan produk dan layanan menggunakan saluran distribusi digital. Pemasaran digital juga disebut sebagai e-marketing dan 9 termasuk iklan digital atau online, yang mengirimkan pesan pemasaran kepada pelanggan. d. Menurut Coviello et al, dalam (Fawaid, 2017) Digital Marketing adalah penggunaan internet dan penggunaan teknologi interaktif lain untuk membuat dan menghubungkan dialog antara perusahaan dan konsumen yang telah teridentifikasi. Mereka juga berpendapat bahwa emarketing merupakan bagian dari e-commerce. e. Menurut Sanjaya dan Tarigan (2009:47) Digital Marketing adalah kegiatan pemasaran termasuk branding yang menggunakan berbagai media. Sebagai contoh yaitu blog, website, e-mail, adwords, dan berbagai macam jaringan media sosial. 
2.2 Indikator Digital Marketing Menurut Yazer Nasdini (2012:32) indikator Digital Marketing yaitu :

a. Accessibility (aksessibilitas). Accessibility adalah kemampuan pengguna untuk mengakses informasi dan layanan yang disediakan secara online periklanan. istilah Accessibility umumnya terkait dengan cara pengguna dapat mengakses situs Sosial media. b. Interactivity (interaktivitas). Interactivity adalah Tingkat komunikasi dua arah yang mengacu pada kemampuan timbal balik komunikasi antara pengiklan dan konsumen, dan menanggapi input yang mereka terima.

c. Entertainment (hiburan). Entertainment adalah kemampuan beriklan untuk memberi kesenangan atau hiburan kepada konsumen. Secara umum memang banyak iklan yang memberikan hiburan sambil menyisipkan informasi-informasi.

d. Credibility (kepercayaan). Credibility adalah bagaimana tingkat kepercayaan konsumen online iklan yang muncul, atau sejauh mana iklan memberikan informasi tentang mereka dapat dipercaya, tidak memihak, kompeten, kredibel dan spesifik.

e. Irritation (kejengkelan). Irritation adalah gangguan yang terjadi dalam iklan online, seperti manipulasi iklan sehingga mengarah pada penipuan atau pengalaman buruk konsumen tentang periklanan online.

f. Informativeness (informative). Kemampuan iklan untuk menyuplai informasi kepada konsumen adalah hakekat dari sebuah iklan. Iklan juga harus memberikan gambaran yang sebenarnya mengenai sebuah produk sehingga bisa memberikan keuntungan ekonomis bagi konsumen.

\subsection{Dimensi Digital Marketing}

Dimensi Digital Marketing penjualan sebagai bagian dari bauran pemasaran 4P menurut Kotler dan Keller (2012:25) yaitu product, price, place, promotion yaitu :

a. Product (produk). Suatu yang dapat ditawarkan kepasar untuk mendapatkan perhatian, agar produk yang dijual mau dibeli, digunakan atau dikonsumsi yang dapat memenuhi suatu keinginan atau kebutuhan dari konsumen. 
b. Price (harga). Sejumlah nilai yang ditukarkan kosumen dengan manfaat dari memiliki atau menggunakan produk atau jasa yang nilainya ditetapkan oleh pembeli dan penjual melalui tawar menawar, atau ditetapkan oleh penjual untuk satu harga yang sama terhadap semua pembeli.

c. Place (tempat). Tempat diasosiasikan sebagai saluran distribusi yang ditujukan untuk mencapai target konsumen. Sistem distribusi ini mencakup lokasi, transportasi, pergudangan dan sebagainya. d. Promotion (promosi). Promosi berarti aktivitas yang menyampaikan manfaat produk dan membujuk pelanggan membelinya.

\subsection{Kepuasan Pelanggan / Konsumen}

Dewasa ini perhatian terhadap kepuasan maupun ketidakpuasanpelanggan telah semakin besar karena pada dasarnya tujuan dari suatuperusahaan adalah untuk menciptakan rasa puas pada pelanggan. Semakin tinggitingkat kepuasan pelanggan, maka akan mendatangkan keuntungan yang semakinbesar bagi perusahaan, karena pelanggan akan melakukan pembelian ulangterhadap produk perusahaan. Namun, apabila tingkat kepuasan yang dirasakanpelanggan kecil, maka terdapat kemungkinan bahwa pelanggan tersebut akanpindah ke produk pesaing.Menurut Kotler, kepuasan adalah tingkat perasaan seseorang setelahmembandingkan kinerja atau hasil yang dia rasakan dibandingkan denganharapannya (Kotler dkk, 2000 : 52). Sedangkan Tse dan Wilton (1988) dalamLupiyoado (2004:349) kepuasan atau ketidakpuasan pelanggan adalah responpelanggan terhadap evaluasi ketidaksesuaian (disconfirmation) yang dirasakanantara harapan sebelumnya dan kinerja aktual produk yang dirasakan setelahpemakaiannya.Wilkie (1990) mendefinisikannya sebagai suatu tanggapan emosionalpada evaluasi terhadap pengalaman konsumsi suatu produk atau jasa. Engel, et al(1990) menyatakan bahwa kepuasan pelanggan merupakan evaluasi purna belidimana alternatif yang dipilih sekurang-kurangnya sama atau melampaui harapanpelanggan, sedangkan ketidakpuasan timbul apabila hasil (outcome) tidakmemenuhi harapan (Tjiptono, 2004 : 349) .Kepuasan pelanggan terhadap suatu produk ataupun jasa, sebenarnyasesuatu yang sulit untuk didapat jika perusahaan jasa atau industri tersebut tidakbenar-benar mengerti apa yang diharapkan oleh konsumen. Untuk produk ataulayanan dengan kualitas yang sama, dapat memberikan tingkat kepuasan yangberbeda-beda 
bagi konsumen yang berbeda. Oleh karena itu, suatu perusahaan20harus selalu memperhatikan kualitas produk maupun pelayanan yang diberikankepada konsumen.Kepuasan pelanggan merupakan respons pelanggan terhadapketidaksesuaian antara tingkat kepentingan sebelumnya dan kinerja aktual yangdirasakannya setelah pemakaian (Rangkuti, 2002:30). Kepuasan pelanggandipengaruhi oleh persepsi kualitas jasa, kualitas produk, harga dan faktor-faktoryang bersifat pribadi serta yang bersifat situasi sesaat.

\section{METODE PENELITIAN}

Dalam penelitian ini diperlukan data dan informasi yang tepat dan akurat. Untuk itu diperlukan beberapa metode yang sesuai dengan perumusan masalah yang dikemukan diatas. Agar mendapatkan data dan informasi yang diperoleh sesuai dengan permasalahan maka terdapat beberapa data yang digunakan adalah sebagai berikut :

1. Berdasarkan tujuannya penelitian ini ditujukan untuk mengetahui digital marketingHotel Kila SenggigiBeach terhadap kepuasan konsumen.

2. Penelitian survey, penelitian ini bertujuan untuk mengumpulkan data dari sejumlah sampel dengan menggunakan kuisioner mengenai mengetahui digital marketing terhadap kepuasan konsumen di Hotel Kila Sengiggi Beach.

3. Berdasarkan metodenya, menggunakan metode analisis deskriptif yaitu dalam suatu penelitian merupakan uraian sistematis tentang teori dan hasil-hasil penelitian yang relevan dengan variabel yang diteliti.

4. Berdasarkan jenis data dan analisis penelitian; penelitian ini menggunakan analisis kuantitatif untuk menentukan mengetahui digital marketing terhadap kepuasan konsumen di Hotel Kila Sengiggi Beach.

\section{HASIL DAN PEMBAHASAN}

\section{Hasil Penelitian}

Berdasarkan hasil penyebaran questioner didapatkan tabulasi data di bawah ini :

\begin{tabular}{|l|l|l|l|l|l|l|l|l|}
\hline Sub variabel & No & Pertanyaan & SS & S & R & TS & STS & Jumlah \\
\hline
\end{tabular}




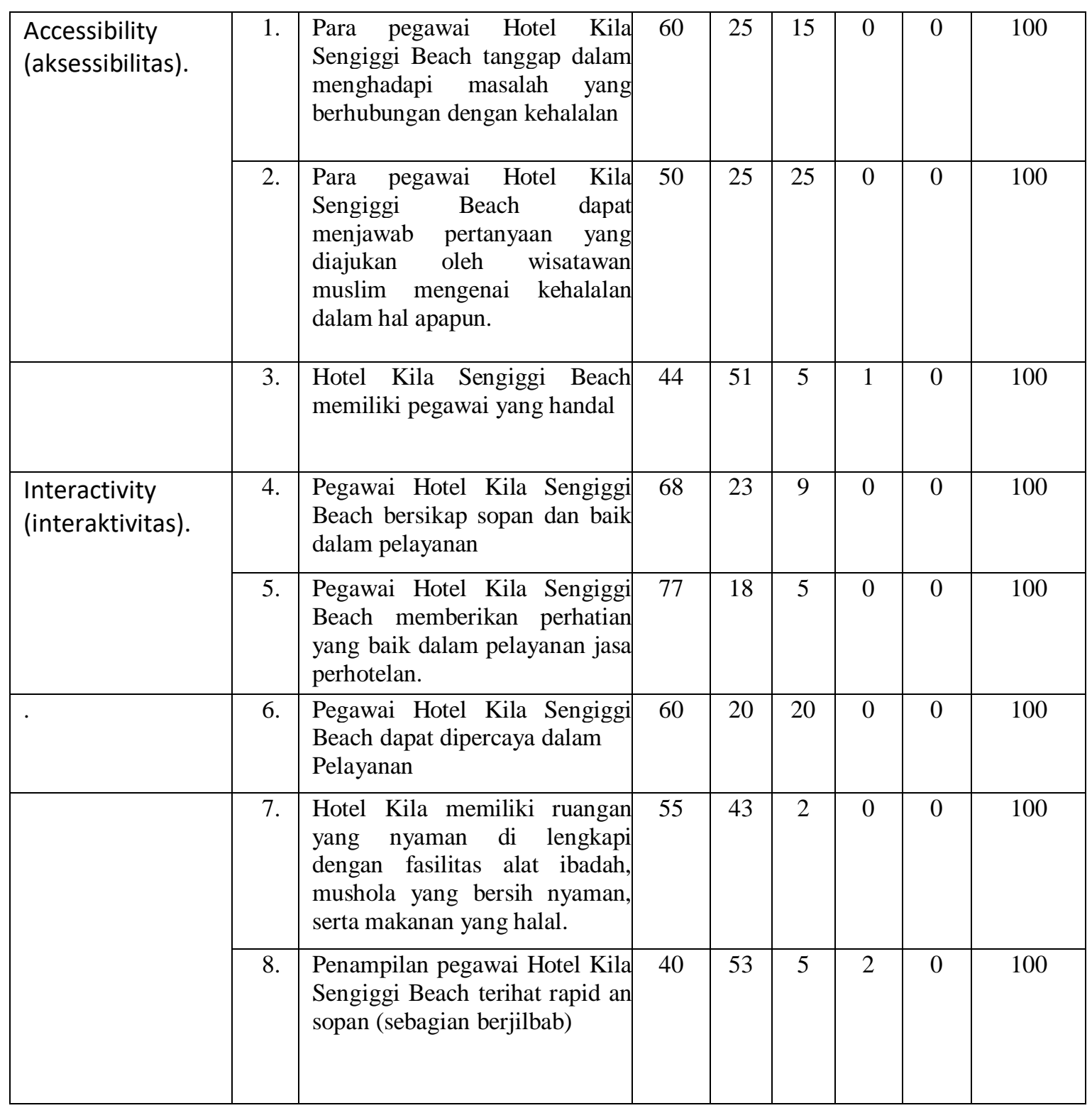

Mengukur kepuasan konsumen terhadap kualitas Digital Marketingyang dilakukan oleh Hotel Kila Sengiggi Beach dengan rumus :

Ao $=\sum\left(b_{i} x e_{1}\right)$

Dimana :

Ao $=$ Kepuasan konsumen terhadap suatu produk atau pelayanan . 
bi = Keyakinan konsumen terhadap Digital Marketing yang dilakukan oleh Hotel Kila Sengiggi Beach ei = Evaluasi konsumen terhadap variabel I dari kualitas pelayanan secara umum tanpa dikaitkan dengan pelayanan hotel lainnya.

$\sum=$ penjumlahan dari variabel I yang dalam hal ini ada 4 variabel.

\section{Analisis}

Hasil rata-rata diurukan dari angka terbesar ke angka terkecil (sesuai kriteria skala), di dapat hasil :

\begin{tabular}{|c|c|}
\hline Skala & Variabel \\
\hline 356 & Accessibility (aksessibilitas). \\
\hline 325 & Interactivity (interaktivitas). \\
\hline
\end{tabular}

dari tabel di atas terlihat adalah kedua variable Digital Marketing Hotel Kila Sengiggi Beach diatas rata-rata nilai 2 yaitu tidak setuju. Jadi semua Digital Marketing itu yang membuat konsumen merasa puas terutama di variable Accessibility (aksessibilitas)., dimana variable ini memiliki rata-rata paling tinggi.

\section{Pembahasan}

Dari hasil penelitian diatas terlihat bahwa Digital Marketing yang dilakukan olehHotel Kila Sengiggi Beach berdampak pada kepuasan konsumen. Dari kedua variable tersebut sudah terlihat jelas bahwa pengaruh Digital Marketing sangat bermanfaat untuk menumbuhkan tingkat kepercayaan konsumen terhadah Hotel Kila Sengiggi Beach.Dengan menggunakan dua varibel ini pihak Hotel merasa terbantukan karena bisa interaksi secara langsung walaupun via online terutama di masa pandemic sekarang ini. Dari semua variable Digital Marketing yang di lakukan oleh pihak hotel, variable Accessibility (aksessibilitas)yang paling tinggi nilaianya. Ini berarti strategi digital marketing yang di lakukan oleh pihak hotel maksimal dalam hasil karena memaksimalkan pemasaran yang di lakukan 
Seiring berjalannya waktu, caraDigital Marketing bukan hanya untuk memasarkan produk dan jasa tapi juga untuk mem-branding, membangun hubungan baik dengan pelanggan, dan meningkatkan penjualan bisnis.Berdasarkan hasil observasi, wawancara, dan dokumentasi yang telah dilakukan dengan melibatkan 100 orang responden pengguna jasa Kila Hotel Senggigi Beach, diketahui hasilnya bahwa sebagian besar responden mengungkapkan rasa puas terhadap pemasaran yang dilakukan oleh pihak hotel.. Artinya asumsi yang diangkat dalam penelitian ini sesuai dengan keadaan sebenarnya, kemudian dapat disimpulkan bahwa penelitian ini menunjukkan hasil yang positif antara Digital Marketing dan Kepuasan Konsumen.

\section{Daftar Pustaka}

Aaker, David A., V. Kumar, \& George S. Day. 2001. Marketing Research, 7thed, John Wiley \&Sons: Inc.

Engel, J. F, R. D. Blackwell, dan P. W. Miniard. 1994. Consumer Behavior (Perilaku Konsumen, alih bahasa : Budijanto). Edisi ke-6. Binarupa Aksara, Jakarta.

http://www.republika.co.id

http://www.lombokpost.net

Husein Umar, Metode Riset Perilaku Konsumen Jasa, Gramedia Pustaka Indonesia, Jakarta, 2003.

Indra Liesander1 , Diah Dharmayanti,S.E.,M.Si.,Ph.D.2,2016,Pengaruh Digital Marketing Terhadap Organizational Performance Dengan Intellectual Capital Dan Perceived Quality Sebagai Variabel Intervening Pada Industri Hotel Bintang Lima Di Jawa Timur, Badan Penerbit Program Studi Manajemen Pemasaran, Fakultas Ekonomi, Universitas Kristen Petra

Jogiyanto. 2008. Pedoman Survei Kuesioner : Mengembangkan Kuesioner, Mengatasi Bias dan Meningkatkan Respon. Badan Penerbit Fakultas Ekonomika dan Bisnis UGM, Yogyakarta.

Kotler, Phillip dan Gary Amstrong, Dasar-Dasar Pemasaran, terjemahan Alexander Sindoro Prehallindo, Jakarta, 2001

London, David L and Albert J Bitta,Consumer Behavior, Mc. Graww-Hill Inc, New York, 2002.

Nazir, M. 2010. Metode Penelitian. Ghalia Indonesia, Bogor.

Nitisusastro, M. 2013. Perilaku Konsumen Dalam Perspektif Kewirausahaan. Alfabeta, Bandung

Schiffman, Leon dan Leslie Lazar Kanuk, Perilaku Konsumen, Indeks, Jakarta, 2004. Sugiyono. 2011. Metode Penelitian Kuantitatif, Kualitatif dan R and D. Alfabeta, Bandung. 